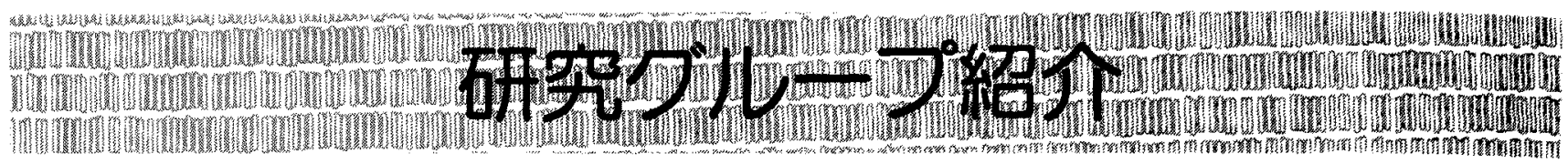

\title{
東京理科大学 静電気関連研究室
}

\section{1.はじめに}

東京理科大学に㧍ける静電気研究は、第二次大戦終了 間もなく、日本でナイロンの生産が開始され、静電気に よる生産障害が発生しだした頃から始められている。当 時情電気測定装置の開発から始めなければならなか。 たとのことで、真空管式の帯電電位測定装置の恐らく第 1 号が残っていた。このような出発点走持つ東京理科大 学の静電気研究は、絶緣体の带電機構や粉体の带電現像 の研究へ移り、現在では基礎面と共に、応用面へも進展 している。

現在、東京理科大学には総合研究所という研究システ ムがあり、その中に静電気部門がおかれ、学内の広い籁 囲から研究者が参加している。静電気部門に参加してい る研究室の研究テーマの概要を紹介する。

\section{2. 理学部化学科 古川猛夫研究室}

(1) 圧雷・焦電性高分子材料古川教授は、高分子 の圧電・焦電性、誘電性の研究を行っている。ポリフッ 化ビニリデン、シアン化ビニリデン共重合体なよ゙、強い 極性を持つ高分子にポーリング処理を加える上、压電・ 焦電性機能材料になる。高分子におけるこれらの機能の 発現機構の解明上、高分子特有の高次满造制御による機 能の向上を目標に研究老行っている。

（2）非線形雷気応答測定システムの開発物質に 電界を加えた時に生じる電流するい性電荷㐫答は、高電 界で注線形性を失い非線形性が顥著となる。非線形応答 を単一周波数の電界に対する高調波応答、あるいは複合 波による和差周波数応答ししてとらえ、関連する物性を 非線形複素数応答関数として測定寸るシステムの開発を 行っている。

\section{3. 工学部機械工学科 吉本成香研究室}

吉本教授は潤滑の研究が専閒で、軸受けなどで発生す る油や水のエアロゾルの飛散を静電気を使って防止する 研究を行っている。機械工学分野での静電気灾用に與昧 を持って、最近総合研究所静電気部門に参加した。

\section{4. 工学部電気工学科 増井典明研究室}

\section{（1）静電気放電(ESD) 半導体デバイスの破壊、} 電子機器の誤動作の原因とされている静電気放電のメ力 ニズム解明のため、带電した人体括よじ絶縁体からの放 電現象について調へている。人体の回路モデルを作りシ ミュレーションを行っている。

（2）イオン発生器の改善物体の荷電や除電に用
いられるコロナ放電式イオン発生器は、イオンと共にオ ゾンを発生する。オゾンは対象物の表面を酸化劣化させ ると共に、人体に上っても有害である。

放電電極を加熱し、オソン発生を抑制する方法もある いて調バている。

(3) オゾン発生器の高効率化通常䨌囲気中で使 用す万無声放電式オゾナイザで、空気中の水分の増加に よるオゾン収率の低下亡誘電体電極の表面抵抗率の変化 之の関係を、放電形態（放電柱の大きさと分布状態）の 変化加検討している。

\section{5. 理工学部教養 児島 紘研究室}

静電気と関係の深いエアロゾルの研究を長年続け、現 在はラドンの研究も行っている。エアロゾルの連続計測 や、大気、地中のラドン濃度変化を継続测定している。 最近村田研究室と共同で、ラドンの電界による蓄積を調 ベている。

\section{6. 理工学部電気工学科 村田雄司研究室}

（1）高分子の带雷機構当研究室で長年継続して いるテーマで、接触带電の機满を説明するために、光電 子放出の特性から高分子の電子構造を明らかにしている。 また、ミクロン単位に絞ったレーザービームを試料表面 で走查するScanning Micro Laser Probe 老用い，電子卜 ラップ分布をモニター上で可視化する装置を作り、トラ ップ分布と接触带電特性の関係を調べている。

（2）高分子の带電特性の制衔 プラズマ処理によ 万高分子の接触・摩擦帯電特性の制御法を研究している。 処理により帯電特性は劇的な変化を示し、正具どちらの 極性にも帯電するようにできる。本方法の忘用の一つと して摩擦帯電式静電粉体塗装用塗料の処理も行っている。

(3) 電子写真電子写真の画質问上の目的で、デジ タル型感光体の動作機構を調へている。また、粒径 0.1 $\mu \mathrm{m}$ 程度まで可能なサブミクロンの超微細乾式トナ一の 研究を行うと共に、トナーの带電機檴を研究している。 新しい電子写真プロセスとして、光電子放出を利用した 直接的静電潜像形成方式などの研究を行っている。

（4）環境關連静電つィルタ一、带電水滴のよる露 の人工消散、自然放射線源の一つであるラドンの静電気 による沈着、などのテーマを扱っている。

（5）電界㐫用静電チャックの吸着力问上と吸着 機構、静電アクチュエーータの研究などを゙手がけている。 村田雄司 (象京理科大学理工学部電気工学科) (平成 11 年 2 月 26 日受付) 